\title{
Hubungan Rasio Neutrofil Limfosit dengan Mortalitas $\leq 28$ hari di General Intensive Care Unit RSUP Dr. Mohammad Hoesin Palembang
}

\author{
Muhammad David Riandy, ${ }^{1}$ Bernhard Arianto Purba, ${ }^{1}$ Yusni Puspita, ${ }^{1}$ Rizal Zainal, ${ }^{1}$ \\ Legiran Siswo ${ }^{2}$ \\ ${ }^{1}$ Departemen Anestesiologi dan Terapi Intensif Fakultas Kedokteran Universitas Sriwijaya/ \\ Rumah Sakit Dr. Moh. Hoesin Palembang, ${ }^{2}$ Departemen Biomedik Fakultas Kedokteran Universitas \\ Sriwijaya/Rumah Sakit Dr. Moh. Hoesin Palembang
}

\begin{abstract}
Abstrak
Rasio neutrofil limfosit adalah metode yang cepat dan sederhana untuk mengevaluasi stres peradangan dan memprediksi mortalitas di ruangan intensif. Penelitian ini bertujuan mengetahui hubungan rasio neutrofil-limfosit dengan mortalitas $\leq 28$ hari di ruangan rawat intensif. Penelitian ini menggunakan desain penelitian cross sectional berdasarkan data sekunder rekam medis dengan sampel semua pasien yang dirawat di ICU RSUP Dr. Mohammad Hoesin Palembang dari Januari-Desember 2018. Didapatkan total sampel sebanyak 562 sampel, dan sebanyak 347 yang memenuhi kriteria inklusi. Pada uji analisis regresi diagnosis, kelompok usia, jenis kelamin dan terapi terhadap nilai rasio neutrofil limfosit, didapatkan bahwa diagnosis merupakan faktor risiko yang dapat memengaruhi nilai rasio neutrofil limfosit $(p=0,001)$. Pada distribusi subjek berdasarkan rasio neutrofil limfosit terhadap mortalitas terdapat rerata rasio neutrofil limfosit pada kelompok yang meninggal adalah $17,75 \pm 15,06$ dan rerata rasio neutrofil limfosit subjek pada kelompok yang hidup adalah $13,63 \pm 10,71$. Dilakukan Uji Mann-Whitney dan didapatkan bahwa terdapat perbedaan rerata antara rasio neutrofil limfosit antara kelompok yang hidup dan meninggal dengan nilai $\mathrm{p}=0,009$. Simpulan, rasio neutrofil limfosit merupakan salah satu biomarker yang dapat memprediksi mortalitas pada pasien di ICU RSUP Dr. Moh. Hoesin Palembang.
\end{abstract}

Kata kunci: Intensive Care Unit (ICU), mortalitas, rasio neutrofil limfosit

\section{Relation between Neutrophil-to-Lympocyte Ratio and $\leq \mathbf{2 8}$ day Mortality in General Intensive Care Unit of Dr. Mohammad Hoesin General Hospital Palembang}

\begin{abstract}
Neutrophil lymphocyte ratio is a fast and simple method for evaluating inflammatory stress and predicting mortality in intensive care. The purpose of this study was to determine the relationship between the ratio of neutrophils to lymphocytes to $\leq 28$ day mortality in the intensive care unit. This was a crosssectional study on secondary data collected from medical records of all patients treated at the ICU of Dr. Mohammad Hoesin General Hospital Palembang during the period of January-December 2018. A total sample of 562 samples was obtained and 347 of them met the inclusion criteria. When diagnosis, age group, gender, and therapy for neutrophil-lymphocyte ratio value were subjected to regression analysis, it was revealed that diagnosis was a risk factor that could affect the neutrophil-lymphocyte ratio value $(\mathrm{p}=0,001)$. When subject distribution was assessed based on neutrophil lymphocyte ratio to mortality, an average neutrophil lymphocyte ratio of $17.75 \pm 15.06$ was observed in the deceased group while the average ratio in survived patients was $13.63 \pm 10.71$. Mann-Whitney test was then performed and a difference in the neutrophil to lymphocyte ratio was found between the survived and deceased groups with a $\mathrm{p}$ value of 0.009 . In conclusion, neutrophil to lymphocyte ratio can be used as one of the biomarkers that can predict mortality in patients treated in intensive care unit.
\end{abstract}

Key words: Intensive Care Unit (ICU), mortality, neutrophil-lymphocyte ratio

Korespondensi: Muhammad David Riandy, dr., SpAn, Departemen Anestesiologi dan Terapi Intensif Fakultas Kedokteran Universitas Sriwijaya/Rumah Sakit Dr. Moh. Hoesin Palembang, Jl. Jend. Sudirman Km 3,5 Palembang, Tlpn (0711) 354088, Email: vidbae@yahoo.com 


\section{Pendahuluan}

Angka mortalitas di Intensive Care Unit (ICU) dapat diprediksi dengan berbagai cara. Beberapa penanda biologis telah diteliti dalam hal diagnostik dan prognostik, akan tetapi tidak semua layanan kesehatan bisa melakukan pemeriksaan tersebut karena fasilitas terbatas dan biaya yang mahal. Sebagai contohnya adalah nilai sequential organ failure assessment (SOFA) yang dapat digunakan untuk memprediksi angka kematian. Namun, SOFA harus dikombinasi dengan nilai acute physiology and chronic health evaluation (APACHE) untuk mendapatkan hasil prognosis yang unggul dibanding dengan memeriksa salah satunya saja. ${ }^{1}$

Acute physiology and chronic health evaluation (APACHE) digunakan dalam 24 jam pertama ketika pasien masuk ke ICU untuk menggambarkan morbiditas pasien, menilai berat penyakit, dan risiko kematian. Skor ini umum digunakan di unit rawat intensif, tetapi membutuhkan beberapa pemeriksaan laboratorium yang kompleks dan membutuhkan waktu, fasilitas, serta dana yang memadai. Demikian juga dengan nilai SOFA yang menggunakan beberapa variabel fisiologi dan laboratorium untuk mendapatkan hasilnya. Hal ini kurang praktis dan beberapa parameter penilaian tidak tersedia di semua tingkat layanan kesehatan misalnya $\mathrm{PaO}_{2} / \mathrm{FiO}_{2}$ dan total bilirubin. ${ }^{1}$

Biomarker yang sering digunakan untuk memprediksi mortalitas pasien yang dirawat di ICU adalah hitung jenis leukosit, CRP, dan prokalsitonin. Namun, pemeriksaan ini tergolong mahal dan tidak semua rumah sakit dapat melakukan. Rasio neutrofillimfosit adalah nilai yang dapat dijadikan biomarker dan dapat dengan mudah dihitung berdasarkan pemeriksaan darah lengkap.

Rasio neutrofil-limfosit adalah metode yang dapat diandalkan, cepat, dan sederhana untuk mengevaluasi stress peradangan. Rasio neutrofil-limfosit mengindikasikan respons pasien terhadap gangguan inflamasi, dengan gambaran peningkatan neutrofil sebagai respons terhadap stres, dan bila respons tersebut berlebihan akan menginduksi apoptosis limfosit. Proses apoptosis terjadi akibat adanya reseptor kematian melalui jalur mitokondria. Hal ini tampak pada pasien anak-anak dengan kegagalan multiorgan. Limfopenia berkepanjangan selama 7 hari dihubungkan dengan risiko infeksi sekunder dan risiko kematian. ${ }^{2}$

Inflamasi sistemik pada pasien dengan penyakit kritis merupakan bagian dari proses perjalanan penyakit. Proses inflamasi memengaruhi jumlah total leukosit, terutama jumlah neutrofil, limfosit, dan monosit. Leukosit berperan penting dalam respons inflamasi sistemik, misalnya pada infeksi berat, trauma, atau syok. Respons imun terhadap endotoksin telah ditemukan dengan adanya peningkatan jumlah neutrofil dan penurunan jumlah limfosit. ${ }^{3}$

Salciccioli dkk. menggunakan rasio neutrofil-limfosit sebagai salah satu penanda fisiologi terhadap mortalitas. ${ }^{2}$ Darmawan memprediksi kejadian henti jantung pada pasien sindrom koroner akut menggunakan rasio neutrofil-limfosit. ${ }^{4}$ Hefferman dkk. mengidentifikasi adanya limfopenia dan neutrofilia pada pasien trauma yang memenuhi kriteria syndrome inflamatory respons system. Peningkatan rasio neutrofillimfosit dapat mengidentifikasi pasien dengan respons fisiologis yang rendah untuk bertahan dari gangguan inflamasi dan secara bersamaan dapat menurunkan tingkat kelangsungan hidup. Rasio neutrofil-limfosit juga telah diteliti pada berbagai jenis keganasan dan dilaporkan menjadi suatu faktor prognostik yang independen pada kasus kanker kolon dan kanker payudara.

Cho dkk. melaporkan bahwa rasio neutrofil-limfosit dikombinasi dengan CA125 berhubungan dengan prognosis yang buruk. ${ }^{5}$ Penggunaan biomarker yang mudah dan murah untuk dilakukan serta memiliki sensitivitas dan spesifisitas yang baik merupakan keuntungan yang berharga pada biomarker. Penelitian ini bertujuan mengetahui hubungan rasio neutrofil-limfosit dengan mortalitas $\leq 28$ hari di ruangan rawat intensif. 


\section{Subjek dan Metode}

Penelitian ini merupakan penelitian deskriptif analitik dengan cross sectional (potong lintang) yang dilakukan di Instalasi Rekam Medik RSUP Dr. Mohammad Hoesin Palembang dari bulan Januari sampai Desember 2018. Subjek penelitian ini adalah pasien yang dirawat di General Intensive Care Unit (GICU) RSUP Dr. Mohammad Hoesin Palembang dari bulan Januari sampai Desember 2018 dan memenuhi kriteria penyertaan penelitian. Adapun kriteria inklusi pada penelitian ini, yaitu usia $\geq 18$ tahun dengan kriterai eksklusi adalah rekam medis tidak lengkap. Setelah mendapat persetujuan dari Komite Etik Penelitian Kesehatan RSUP Dr. Mohammad Hoesin/FK Universitas Sriwijaya no. 202/ kepkrsmhfkunsri/2019, pengambilan sampel dilakukan dengan cara total sampling. Semua rekam medis pasien yang dirawat di GICU yang memenuhi kriteria inklusi dikumpulkan, kemudian dilakukan identifikasi (nama, usia, jenis kelamin). Data yang diambil adalah nilai neutrofil dan limfosit pada hari pertama pasien masuk GICU kemudian dilakukan observasi dari rekam medis apakah terjadi kematian atau tidak dalam waktu $\leq 28$ hari. Analisis data dilakukan dengan Uji Mann-Whitney.

\section{Hasil}

Penelitian uji prognostik ini telah dilakukan di ruang Instalasi Rekam Medik RSMH Palembang dengan sampel, yaitu semua pasien yang dirawat di ICU RSMH Palembang dari bulan Januari-Desember 2018. Total sampel didapatkan sebanyak 562 sampel dan 347 subjek yang memenuhi kriteria inklusi dan tidak termasuk kriteria eksklusi dengan perincian subjek yang hidup 114 orang dan yang meninggal 233 orang. Distribusi subjek berdasarkan usia, jenis kelamin, diagnosis masuk ICU, riwayat merokok, riwayat terapi

Tabel 1 Karakteristik Umum Penelitian $(n=347)$ dan Distribusi Subjek Berdasarkan Variabel Perancu terhadap Mortalitas Subjek

\begin{tabular}{|c|c|c|c|c|}
\hline \multirow[b]{2}{*}{ Variabel } & \multirow[b]{2}{*}{ f (\%) } & \multicolumn{2}{|c|}{ Mortalitas } & \multirow[b]{2}{*}{ Nilai p } \\
\hline & & $\begin{array}{c}\text { Mati } \\
\text { n (\%) }\end{array}$ & $\begin{array}{l}\text { Hidup } \\
\text { n (\%) }\end{array}$ & \\
\hline $\begin{array}{l}\text { Usia (tahun) } \\
\leq 20 \\
21-40 \\
41-60 \\
>60\end{array}$ & $\begin{array}{c}13(3,7) \\
104(30,0) \\
140(40,3) \\
90(25,9)\end{array}$ & $\begin{array}{c}6(5,3) \\
22(19,3) \\
41(36,0) \\
45(39,5)\end{array}$ & $\begin{array}{c}7(3,0) \\
82(35,2) \\
99(42,5) \\
45(19,3)\end{array}$ & 0,000 \\
\hline $\begin{array}{l}\text { Jenis kelamin } \\
\text { Laki-Laki } \\
\text { Perempuan }\end{array}$ & $\begin{array}{l}145(41,8) \\
202(58,2)\end{array}$ & $\begin{array}{l}55(48,2) \\
59(51,8)\end{array}$ & $\begin{array}{c}90(38,6) \\
143(61,4)\end{array}$ & 0,088 \\
\hline $\begin{array}{l}\text { Diagnosis } \\
\text { Autoimun } \\
\text { Infeksi } \\
\text { Kardiovaskular } \\
\text { Malignansi } \\
\text { Serebrovaskular }\end{array}$ & $\begin{array}{c}4(1,2) \\
52(15,0) \\
77(22,2) \\
105(30,3) \\
109(31,4)\end{array}$ & $\begin{array}{c}2(1,8) \\
22(19,3) \\
21(18,4) \\
22(19,3) \\
47(41,2)\end{array}$ & $\begin{array}{c}2(0,9) \\
30(12,9) \\
56(24,0) \\
83(35,6) \\
62(26,6)\end{array}$ & 0,003 \\
\hline $\begin{array}{l}\text { Riwayat merokok } \\
\text { Tidak } \\
\text { Ya }\end{array}$ & $\begin{array}{c}328(94,5) \\
19(5,5)\end{array}$ & $\begin{array}{c}7(6,1) \\
107(93,9)\end{array}$ & $\begin{array}{c}12(5,2) \\
221(94,8)\end{array}$ & 0,703 \\
\hline $\begin{array}{l}\text { Riwayat terapi } \\
\text { Kemoterapi } \\
\text { Kortikosteroid }\end{array}$ & $\begin{array}{c}6(1,7) \\
15(4,3)\end{array}$ & $\begin{array}{l}3(2,6) \\
6(5,3)\end{array}$ & $\begin{array}{l}3(1,3) \\
9(3,9)\end{array}$ & \\
\hline
\end{tabular}

Keterangan: Uji Pearson chi-square 
terhadap mortalitas tercantum pada Tabel 1.

Distribusi subjek berdasarkan variabel perancu terhadap rasio neutrofil limfosit, yaitu distribusi subjek berdasarkan kelompok usia, jenis kelamin, diagnosis masuk ICU, riwayat merokok, dan terapi terhadap rasio neutrofil limfosit tidak terdistribusi normal terhadap variabel perancu dengan uji normalitas Kolmogorov-Smirnov seperti pada Tabel 2.

Pada uji analisa regresi linier variabel perancu terhadap rasio neutrofil limfosit, didapatkan bahwa hanya diagnosis yang merupakan faktor risiko yang dapat memengaruhi rasio neutrofil limfosit $(\mathrm{p}=0,001)$, dibanding dengan jenis kelamin $(\mathrm{p}=0,317)$, kelompok usia $(\mathrm{p}=0,697)$, merokok $(0,704)$, dan terapi $(p=0,738)$. Pada uji analisis regresi linier variabel perancu terhadap mortalitas, didapatkan bahwa kelompok jenis kelamin $(p=0,183)$, kelompok usia $(p=0,001)$ merupakan faktor risiko yang dapat memengaruhi mortalitas subjek dibanding diagnosis $(p=0,944)$, merokok $(p=0,906)$ dan terapi $(p=0,273)$. Pada uji analisis regresi linier rasio neutrofil limfosit terhadap mortalitas, didapatkan bahwa rasio neutrofil limfosit merupakan faktor risiko yang dapat memengaruhi mortalitas $(\mathrm{p}=0,004$ dengan $\mathrm{y}=\mathrm{a}+\mathrm{bx} ; \mathrm{y}=17,758-4,116 \mathrm{x} ; \mathrm{x}$ adalah mortalitas dengan value 1, maka didapatkanlah $\mathrm{y}=13,642 ; \mathrm{y}$ adalah nilai cut-off rasio neutrofil limfosit dengan nilai $\mathrm{R}=0,21$ yang berarti rasio neutrofil limfosit berperan dalam prediksi mortalitas sebesar $21 \%$ ).

Tabel 2 Distribusi Subjek Berdasarkan Variabel Perancu Terhadap Rasio Neutrofil Limfosit Subjek

\begin{tabular}{|c|c|c|c|c|}
\hline \multirow{2}{*}{ Variabel } & \multicolumn{3}{|c|}{ Rasio Neutrofil Limfosit } & \multirow{2}{*}{ Nilai $_{1}$} \\
\hline & Mean \pm SD & Median & Min.-Maks. & \\
\hline Usia (tahun) & & & & $0,110^{\mathrm{a}}$ \\
\hline$\leq 20$ & $16,10 \pm 24,90$ & 10,25 & $2,07-97$ & \\
\hline $21-40$ & $15,37 \pm 12,48$ & 12,71 & $1,43-98$ & \\
\hline $41-60$ & $14,25 \pm 10,07$ & 11,06 & $1,16-48$ & \\
\hline$>60$ & $15,54 \pm 13,28$ & 12,35 & $0,89-97,00$ & \\
\hline Jenis kelamin & & & & $0,869^{b}$ \\
\hline Laki-laki & $14,84 \pm 11,91$ & 11,12 & $0,91-97$ & \\
\hline Perempuan & $15,09 \pm 12,81$ & 12,21 & $0,89-98$ & \\
\hline Diagnosis & & & & $0,101^{\mathrm{a}}$ \\
\hline Autoimun & $40,81 \pm 12,39$ & 46,75 & $22,25-47,50$ & \\
\hline Infeksi & $18,63 \pm 16,55$ & 14,25 & $0,91-96,09$ & \\
\hline Kardiovaskular & $14,19 \pm 12,60$ & 11,25 & $2,58-97,00$ & \\
\hline Malignansi & $15,02 \pm 12,30$ & 12,71 & $0,89-98,00$ & \\
\hline Serebrovaskular & $12,85 \pm 8,21$ & 10,62 & $2,07-48,00$ & \\
\hline Riwayat merokok & & & & $0,482^{\mathrm{b}}$ \\
\hline Merokok & $15,79 \pm 10,47$ & 14,50 & $3,41-47$ & \\
\hline Tidak merokok & $14,98 \pm 12,54$ & 12,00 & $0,89-98$ & \\
\hline \multicolumn{5}{|l|}{ Terapi } \\
\hline Kemoterapi & $25,94 \pm 35,95$ & 13,95 & $0,91-98,00$ & \\
\hline Kortikosteroid & $14,95 \pm 6,64$ & 13,00 & $7,00-29,67$ & \\
\hline
\end{tabular}

Keterangan: aUji One-Way ANOVA, bUji Mann-Whitney 
Tabel 3 Distribusi Subjek Berdasarkan Neutrofil, Limfosit, Rasio Neutrofil Limfosit terhadap Mortalitas Subjek

\begin{tabular}{lccc}
\hline \multirow{2}{*}{ Variabel } & \multicolumn{2}{c}{ Mortalitas } & Nilai p \\
\cline { 2 - 3 } & & Hidup & 0,246 \\
Neutrofil & $86,66 \pm 6,90$ & $85,13 \pm 8,56$ & \\
Mean & 88,00 & 87,00 & \\
Median & $42-97$ & $34-98$ & 0,005 \\
Min.-Maks. & & & \\
Limfosit & $7,64 \pm 5,44$ & $9,54 \pm 6,78$ & \\
Mean & 6,00 & 8,00 & 0,009 \\
Median & $1-46$ & $1-45$ & \\
Min.-Maks. & & & \\
Rasio neutrofil limfosit & $17,75 \pm 15,06$ & $13,63 \pm 10,71$ & \\
Mean & 14,41 & 11,00 & \\
Median & $0,91-97,00$ & $0,89-98,00$ & \\
Min.-Maks. & & & \\
\hline
\end{tabular}

Keterangan: Uji Mann-Whitney

Pada distribusi subjek berdasarkan rasio neutrofil limfosit terhadap mortalitas terdapat rerata rasio neutrofil limfosit pada kelompok yang meninggal lebih tinggi $(17,75 \pm 15,06)$ dibanding dengan rerata rasio neutrofil limfosit subjek pada kelompok yang hidup $(13,63 \pm 10,71)$. Uji normalitas menggunakan Kolmogorov-Smirnov didapatkan bahwa rasio neutrofil limfosit tidak terdistribusi normal terhadap mortalitas (Tabel 3). Perbedaan rerata neutrofil limfosit antara kedua kelompok berdasarkan Uji Mann-Whitney berbeda bermakna $(p>0,05)$.

\section{Pembahasan}

Neutrofil merupakan sel darah putih yang berfungsi sebagai garis pertahanan tubuh terhadap zat asing. Neutrofil bersifat fagosit dan dapat masuk ke dalam jaringan yang rusak. Sirkulasi neutrofil dalam darah, yaitu sekitar 10 jam dan dapat hidup selama 1-4 hari pada saat berada dalam jaringan ekstravaskular. Neutrofil bersama makrofag akan tertarik ke arah jaringan yang meradang dengan cara kemotaksis. Proses kemotaksis bergantung pada perbedaan konsentrasi bahan-bahan kemotaksis. Pada daerah dekat sumber, konsentrasi bahan-bahan ini paling tinggi yang menyebabkan gerakan terarah dari sel darah putih. Fungsi yang terpenting dari neutrofil dan makrofag adalah fagositosis, yaitu pencernaan seluler terhadap bahan yang mengganggu. Saat memasuki jaringan, neutrofil merupakan sel-sel matur yang dapat segera memulai fagositosis. ${ }^{6}$ Peningkatan jumlah neutrofil (neutrofilia) dapat terjadi karena respons fisiologis terhadap stres, misalnya olahraga, cuaca yang ekstrim, perdarahan atau hemolisis akut, melahirkan, dan stres emosi akut. Keadaan patologis yang menyebabkan neutrofilia diantaranya infeksi akut, inflamasi, kerusakan jaringan, gangguan metabolik, dan leukemia mielositik.

Limfosit sebagian besar disimpan dalam berbagai area jaringan limfoid kecuali pada sedikit limfosit yang secara temporer diangkat dalam darah. Limfosit terus menerus memasuki sistem sirkulasi dan pengaliran limfe dari nodus limfe dan jaringan limfoid lain. Setelah beberapa jam, limfosit berjalan kembali ke jaringan dengan dengan cara diapedesis dan selanjutnya kembali memasuki limfe dan kembali ke jaringan limfoid atau 
ke darah, demikian seterusnya. Limfosit memiliki masa hidup berminggu-minggu, berbulan-bulan atau bahkan bertahun-tahun, bergantung pada kebutuhan tubuh akan selsel tersebut. ${ }^{6}$

Rasio neutrofil limfosit merupakan rasio dari jalur sistem imunologi yang berbeda dan saling melengkapi, mengintegrasikan peran neutrofil yang bertanggung jawab terhadap reaksi inflamasi non-spesifik dan limfopenia yang merupakan penanda stress fisiologis yang berat serta kondisi tubuh yang buruk. Sehingga rasio neutrofil limfosit akan menggambarkan dua jalur sistem imunologi yang penting dan bersifat prediktif dibanding dengan hanya sebagai parameter saja. ${ }^{7}$

Pada distribusi subjek berdasar usia terhadap mortalitas terdapat 39,5\% subjek yang berusia $>60$ tahun pada kelompok yang meninggal dan $42,5 \%$ subjek yang berusia 41-60 tahun pada kelompok yang hidup. Pada distribusi subjek berdasarkan kelompok usia terhadap rasio neutrofil limfosit, terdapat rerata rasio neutrofil limfosit tertinggi pada kelompok >60 tahun adalah 15,54 13,28. Pada Uji Pearson chi-square ditemukan bahwa kelompok usia berhubungan terhadap mortalitas subjek penelitian. Mortalitas meningkat pada usia tua karena prevalensi penyakit kronis, penurunan fungsional organ, dan serangan penyakit akut seperti sepsis, gagal ginjal akut, gagal napas akut yang membutuhkan penyokong hidup seperti ventilasi mekanik. ${ }^{8}$ Sedangkan pada uji OneWay Anova ditemukan bahwa tidak terdapat perbedaan rerata rasio neutrofil limfosit terhadap kelompok usia subjek penelitian. Rasio neutrofil limfosit pada semua pasien yang dirawat di ruang ICU meningkat disebabkan karena respons stres peradangan penyakit yang mendasarinya. ${ }^{9}$

Pada distribusi subjek berdasarkan jenis kelamin terhadap mortalitas terdapat sebanyak 48,2\% subjek yang berjenis kelamin laki-laki dan 51,8\% subjek yang berjenis kelamin perempuan pada kelompok yang meninggal, sedangkan terdapat sebanyak $38,6 \%$ subjek yang berjenis kelamin lakilaki dan $61,4 \%$ subjek yang berjenis kelamin perempuan pada kelompok yang hidup. Pada distribusi subjek berdasar jenis kelamin terhadap rasio neutrofil limfosit, terdapat rerata rasio neutrofil limfosit pada kelompok laki-laki dan perempuan adalah $14,84 \pm 11,91$ dan 15,09 $\pm 12,81$.

Pada uji Pearson chi-square ditemukan bahwa jenis kelamin tidak berhubungan terhadap mortalitas subjek penelitian, sedangkan pada uji Mann-Whitney ditemukan bahwa tidakterdapat perbedaan rasio neutrofil limfosit terhadap jenis kelamin. Hal ini sama dengan beberapa penelitian yang mengatakan bahwa rasio neutrofil limfosit lebih tinggi pada perempuan lebih tinggi dibanding dengan laki-laki. ${ }^{10}$

Nilai rasio neutrofil limfosit berbeda antar jenis kelamin pada usia yang sama. Rasio neutrofil limfosit pada perempuan lebih tinggi pada kelompok usia $<50$ tahun dibanding dengan laki-laki. Hal ini dikaitkan dengan respons kortisol terhadap stres fisik pada perempuan lebih tinggi dibanding dengan laki-laki. ${ }^{10}$ Akan tetapi, pada kelompok usia $>50$ tahun nilai rasio neutrofil limfosit laki-laki lebih tinggi pada perempuan. Hal ini disebabkan oleh adanya perubahan hematopoiesis pada kadar estrogen yang berbeda selama menopause.

Hormon seks yang diwakili estrogen dan progesterone dapat meningkatkan rekrutmen neutrofil dari sumsum tulang yang signifikan pada wanita berusia $>40$ tahun. Penurunan jumlah neutrofil pada perempuan menopause dengan jumlah limfosit yang relatif tidak berubah menghasilkan penurunan nilai rasio neutrofil limfosit.

Pada distribusi subjek berdasar diagnosis masuk ICU terhadap mortalitas terdapat sebanyak 41,2\% subjek yang didiagnosis dengan serebrovaskular; $19,3 \%$ subjek yang didiagnosis dengan infeksi dan malignansi; $18,4 \%$ subjek yang didiagnosis kardiovaskuler; dan 1,8\% subjek yang didiagnosis dengan autoimun pada kelompok yang meninggal. Pada distribusi subjek berdasarkan diagnosa masuk ICU terhadap rasio neutrofil limfosit, terdapat rerata rasio neutrofil limfosit adalah $40,81 \pm 12,39$ pada kelompok autoimun; 
$18,63 \pm 16,55$ pada kelompok Infeksi; $14,19 \pm 12,60$ pada kelompok kardiovaskular; $15,02 \pm 12,36$ pada kelompok malignansi; $12,85 \pm 8,21$ pada kelompok serebrovaskular.

Pada uji Pearson chi-square ditemukan bahwa diagnosis berhubungan terhadap mortalitas subjek penelitian, sedangkan pada uji One-Way Anova ditemukan bahwa tidak terdapat perbedaan rerata rasio neutrofil limfosit pada kelompok diagnosis. Penyakit yang umumnya menjadi penyebab dirawat di ICU adalah penyakit serebrovaskular, gagal ginjal dan penyakit jantung iskemik. Sistem sirkulasi (penyakit serebrovaskular, penyakit jantung iskemik dan penyakit jantung kongestif) merupakan penyebab kematian paling sering pada pasien yang dirawat di ICU dengan persentase sebesar $42,91 \%$ diikuti gagal ginjal $(20,36 \%)$, keganasan $(6,99 \%)$ dan penyakit infeksi sebesar 6,8\%. ${ }^{11}$ Hasil yang berbeda didapatkan pada penelitian yang dilakukan oleh Braber dan Arthur pada tahun 2010 dimana sepsis menempati urutan pertama sebagai penyebab kematian di ICU sebesar 48,3\% lalu diikuti kerusakan otak irreversibel dan penyakit jantung kongestif sebesar $14,5 \%$ dan $13,8 \%$ berturut-turut. ${ }^{12}$

Pada distribusi subjek berdasarkan riwayat merokok terhadap mortalitas terdapat sebanyak $94,4 \%$ subjek yang tidak memiliki riwayat merokok dan $5,6 \%$ subjek yang memiliki riwayat merokok pada kelompok yang meninggal, sedangkan terdapat sebanyak $94,8 \%$ subjek yang tidak memiliki riwayat merokok dan 5,2\% subjek yang memiliki riwayat merokok pada kelompok yang hidup. Pada distribusi subjek berdasarkan riwayat merokok terhadap rasio neutrofil limfosit, terdapat rerata rasio neutrofil limfosit pada kelompok yang merokok dan tidak merokok adalah $15,79 \pm 10,47$ dan $14,98 \pm 12,54$. Rerata rasio neutrofil limfosit pada kelompok yang merokok lebih tinggi dibanding dengan kelompok yang tidak merokok.

Pada uji analisis Pearson chi-square didapatkan bahwa tidak terdapat hubungan antara riwayat merokok terhadap mortalitas, sedangkan pada uji analisis Mann-Whitney tidak terdapat perbedaan rerata rasio neutrofil limfosit terhadap riwayat merokok. Hal ini berbeda dengan beberapa penelitian yang mengatakan bahwa pajanan terhadap rokok secara konstan diketahui memicu inflamasi kronik akibat kerusakan vaskuler yang menyebabkan disfungsi endotel. Hal ini berlangsung terus menerus dan memicu aktivasi neutrofil pada daerah inflamasi tersebut, dan menyebabkan adanya modulasi nilai rasio neutrofil limfosit.

Hal serupa ditemukan pada hipertensi dan dislipidemia yang juga dapat memicu disfungsi endotel. ${ }^{13}$ Nilai rasio neutrofil limfosit akan lebih tinggi pada populasi dengan keadaan kronis, misalnya populasi dengan riwayat diabetes dan penyakit jantung, pada perokok, serta semua kondisi yang diketahui dapat meningkatkan kondisi inflamasi. ${ }^{13}$

Pada distribusi subjek berdasarkan terapi terhadap mortalitas yang mendapatkan kemoterapi, kortikosteroid, maupun subjek yang tidak mendapatkan terapi kemoterapi atau kortikosteroid pada kelompok yang meninggal dengan uji Pearson chi-square didapatkan hasil tidak terdapat hubungan. Sedangkan distribusi subjek berdasarkan terapi terhadap rasio neutrofil limfosit pada kelompok kemoterapi terlihat lebih tinggi dibanding kelompok lainnya namun pada uji one-way Anova didapatkan bahwa tidak terdapat perbedaan rerata rasio neutrofil limfosit terhadap riwayat terapi.

Penelitian yang dilakukan pada tahun 2015 yang meneliti tentang rasio neutrofil limfosit awal sebagai biomarker prognostik pada pria mCRPC yang menerima kemoterapi berbasis taxane mendapatkan bahwa overall survival (OS) secara signifikan lebih baik pada pasien dengan rasio neutrofil limfosit $<5 \quad(n=28)$ dibanding dengan mereka yang rasio neutrofil limfosit $>5 \quad(n=14)$, dengan median OS 32 bulan vs 14,9 bulan masing-masing (HR 2,15, 95\% CI 1,07-4,33, p=0,0003). Progression-free survival (PFS) adalah 10 bulan pada mereka dengan rasio neutrofil limfosit $<5$ vs 5 bulan pada mereka dengan rasio neutrofil limfosit $>5$ (HR 2, 95\% CI 0,99-3,66, p=0,01). Analisis multivariat menegaskan rasio neutrofil limfosit $(p=0,004)$ sebagai faktor prognostik 
independen untuk OS. ${ }^{14}$

Pada distribusi subjek berdasarkan neutrofil terhadap mortalitas terdapat rerata neutrofil pada kelompok yang meninggal dengan uji Mann-Whitney menunjukkan tidak terdapat perbedaan rerata neutrofil terhadap mortalitas. Pada penyakit infeksi dan kardiovaskular, netrofilia menunjukkan angka kematian yang meningkat sedangkan pada kasus malignansi, netropenia berkaitan dengan mortalitas yang meningkat.

Pada penelitian ini tidak ditelusuri lebih lanjut nilai rerata netrofil antara kasus malignansi dan non malignansi. Peningkatan hitung jenis neutrofil diketahui berhubungan dengan tingginya MACE pada pasien dengan infark miokard akut dan penyakit pembuluh darah arteri perifer. Khususnya pada pasien dengan infark miokardium akut didapatkan kesesuaian antara peningkatan hitung neutrofil dengan luasnya daerah miokardium yang mengalami nekrosis. ${ }^{15}$ Neutropenia dapat terjadi pada sepsis yang berat dan juga sering terjadi akibat efek samping umum kemoterapi penyakit kanker yang walaupun bersifat sementara, dapat menyebabkan disfungsi kekebalan tubuh. Konsekuensi klinis neutropenia ini dapat menyebabkan gagal napas akut ataupun sepsis sehingga netropenia menjadi faktor risiko independen yang menyebabkan hasil yang buruk pada perawatan di ruang ICU. ${ }^{16}$

Distribusi subjek berdasarkan limfosit terhadap mortalitas terdapat perbedaan rerata limfosit terhadap mortalitas. Penelitian tentang hitung jenis limfosit mendapatkan bahwa hitung limfosit yang rendah berhubungan dengan mortalitas yang lebih tinggi dan hasil akhir kejadian kardiovaskular yang buruk pada pasien dengan nyeri dada, penyakit jantung koroner stabil, angina pektoris tidak stabil dan gagal jantung kronik.

Mekanisme yang mendasari peran dari limfosityang rendah dan hasil akhir yang buruk tersebut menggambarkan stres fisiologis yang tinggi melalui pelepasan kortisol (setelah kondisi akut seperti infark miokardial akut) dan disregulasi respons inflamasi. Sel limfosit $\mathrm{T}$ memiliki sifat yang unik dalam beberapa pembagian subset, diketahui beberapa subtipe akan meningkatkan dan beberapa yang lain mengendalikan respons inflamasi dan sistem imunitas. ${ }^{17}$

Selanjutnya subjek berdasarkan rasio neutrofil limfosit terhadap mortalitas dengan Uji Mann-Whitney didapatkan bahwa terdapat perbedaan rerata NLR terhadap mortalitas. Hasil yang sama juga ditemukan pada beberapa penelitian, namun nilai baku rasio neutrofil limfosit belum tersedia secara umum. Nilai rasio neutrofil limfosit akan berbeda pada metode yang berbeda dan populasi yang berbeda. Hasil penelitian Forget dkk, menunjukkan bahwa batasan nilai rasio neutrofil limfosit pada orang dewasa nongeriatrik dan dalam kondisi sehat adalah 0,78-3,58. ${ }^{7}$ Azab dkk. melaporkan bahwa nilai rerata rasio neutrofil limfosit adalah 2,15 dengan nilai rata-rata neutrofil 4,27 x 1.000 $\mathrm{sel} / \mu \mathrm{L}$ dan rata-rata limfosit $2,14 \times 1.000 \mathrm{sel} /$ $\mu \mathrm{L}^{13}$

Penelitian yang dilakukan oleh Xuan Liu pada tahun 2016 tentang nilai prognosis rasio neutrofil limfosit terhadap mortalitas pasien sepsis menyatakan bahwa rasio neutrofil limfosit memiliki kekuatan sederhana untuk memprediksi hasil yang buruk seperti yang disarankan oleh AUC dari 0,695 $\pm 0,036$, yang kurang dari skor dasar APACHE II $(0,828 \pm$ $0,026)$ tetapi lebih besar daripada neutrofil $(0,633 \pm 0,036)$ dan limfosit $(0,650 \pm 0,035)$. Rasio neutrofil limfosit $\geq 23,8$ diusulkan sebagai nilai batas optimal, yang memberikan sensitivitas $81,3 \%$ dan spesifisitas $53,6 \%$ untuk memprediksi mortalitas pada sepsis.

Penelitian yang dilakukan oleh Karagoz pada tahun 2019 yang melakukan penelitian rasio platelet terhadap limfosit dan neutrofil terhadap limfosit sebagai prediktor kuat angka kematian dalam populasi perawatan intensif mendapatkan bahwa rasio neutrofil limfosit dari subjek yang selamat dan meninggal masing-masing adalah 3,6 (0,2-31) dan 9,5 (140). Rasio neutrofil limfosit secara signifikan lebih tinggi pada kelompok yang meninggal dibanding dengan yang selamat $(\mathrm{p}<0,001)$. Rasio neutrofil limfosit yang lebih tinggi dari 4,9 memiliki sensitivitas $84 \%$ dan spesifisitas 
$67 \%$ dalam memilih pasien yang meninggal (AUC: $0,80, p<0,001) .{ }^{9}$ Rasio neutrofil limfosit dapat digunakan sebagai penanda inflamasi dalam praktik perawatan intensif karena respons fisiologis leukosit yang bersirkulasi terhadap stres inflamasi menyebabkan peningkatan jumlah neutrofil dan penurunan jumlah limfosit.

Neutrofil yang diaktifkan mengeluarkan enzim seperti asam fosfatase, mieloperoksidase, dan elastase, yang menyebabkan kerusakan jaringan. Dengan demikian, rasio neutrofil limfosit diusulkan sebagai penanda yang mencerminkan beban inflamasi dengan peningkatan jumlah neutrofil dan menunjukkan stres fisiologis dan kondisi kesehatan yang buruk dengan penurunan jumlah limfosit. Memang, kematian akibat penyakit jantung koroner meningkat dengan tingkat rasio neutrofil limfosit yang lebih tinggi dalam studi dalam literatur.

Rasio neutrofil limfosit telah diperkenalkan sebagai penanda sederhana, namun efektif dari kondisi inflamasi, karena ditemukan berkorelasi dengan keparahan dan prognosis subjek dengan sepsis bila dibanding dan dievaluasi bersama dengan skor prognostik, seperti APACHE 2 dan SOFA. Mirip dengan pengetahuan yang ditemukan dalam literatur, penelitian ini menunjukkan bahwa NLR dapat berfungsi sebagai faktor prognostik dalam populasi ICU. ${ }^{19,20}$

\section{Simpulan}

Terdapat perbedaan rerata rasio neutrofil limfosit berhubungan secara signifikan terhadap mortalitas di ruangan General Intensive Care Unit (GICU) RSUP dr. Muhammad Hoesin Palembang. Penelitian ini dapatmenjadi informasi awal bahwa rasio neutrofil limfosit dapat dijadikan sebagai suatu alat prediktor kematian, namun perlu dilakukan penelitian lebih lanjut dan dengan desain penelitian, yaitu penelitian kohort untuk mengetahui sejauh mana nilai rasio neutrofil limfosit ini bermakna dan didapatkan data rasio neutrofil limfosit yang lebih akurat dengan sensitivitas dan spesifisitas yang lebih baik.

\section{Daftar Pustaka}

1. Minne L, Abu-Hanna A, Jonge E de. Evaluation of SOFA-based models for predicting mortality in the ICU: a systematic review. Crit Care. 2008;12(6):1-13.

2. Salciccioli JD, Marshall DC, Pimentel MAF, Santos MD, Pollard T, Celi AA, dkk. The association between the neutrophil-tolymphocyte ratio and mortality in critical illness: an observational cohort study. Crit Care. 2015;19(1):1-8.

3. Jilma B, Blann A, Pernerstorfer T, Stohlawetz P, Eichler H, Vondrovec B, dkk. Regulation of adhesion molecules during human endotoxemia no acute effects of aspirin. Am J Respir Crit Care Med. 1999;159(14):857-63.

4. Darmawan. Peran rasio netrofil limfosit sebagai prediktor major adverse cardiac events tujuh hari dalam perawatan pada pasien sindrom koroner akut. Universitas Indonesia; 2016.

5. Cho H, Hur HW, Kim SW, Kim SH, Kim JH, Kim YT, dkk. Pre-treatment neutrophil to lymphocyte ratio is elevated in epithelial ovarian cancer and predicts survival after treatment. Cancer Immunol Immunother. 2009;58(1):15-23.

6. Silbernagl S. Blood. Dalam: Silbernagl S, Lang F, penyunting. Color Atlas of Pathophysiology. New York: Thieme; 2000. hlm. 28-65.

7. Forget $\mathrm{P}$, Khalifa C, Defour JP, Latinne D, Van Pel MC, De Kock M. What is the normal value of the neutrophil-to-lymphocyte ratio? BMC Res Notes. 2017;10(1):1-4.

8. Khouri T, Kabeshova A, Annweiler C, Mercat A, Beauchet O, Lerolle N. Amount of care per survivor in young and older patients hospitalized in intensive care unit: a retrospective study. J Gerontol A Biol Sci Med Sci. 2014;(23):1-8.

9. Karagoz I, Yoldas H. Platelet to lymphocyte and neutrophil to lymphocyte ratios as strong predictors of mortality in intensive care population. Rev Assoc Med Bras. 2019;65(5):633-6.

10. Mi SG, Soo JC, Jie AK, Justin SK, Tae HK, 
Sang ML, et al. Effects of gender on white blood cell populations and neutrophillymphocyte ratio following gastrectomy in patients with stomach cancer. J Korean Med Sci. 2007;22(SUPPL.):104-8.

11. Omar MAK, Aram FO, Banafa NS. Causes of mortality among critically ill patients admitted in intensive care unit. Bahrain Med Bull. 2015;37(3):178-80.

12. Braber A, Van Zanten ARH. Unravelling post-ICU mortality: predictors and causes of death. Eur J Anaesthesiol. 2010;27(5):486-90.

13. Azab B, Camacho-Rivera M, Taioli E. Average values and racial differences of neutrophil lymphocyte ratio among a nationally representative sample of United States subjects. PLoS One. 2014;9(11):1-6.

14. McLachlan JM, Chan DL, Crumbaker MA, Marx GM. Neutrophil-lymphocyte ratio prior to steroids as a prognostic marker in men with metastatic castration-resistant prostate cancer. Cancer Treat Commun. 2015;4(August):81-5.

15. Ghaffari S, Nadiri M, Pourafkari L, Sepehrvand N, Movasagpoor A, Rahmatvand N, dkk. The predictive value of total neutrophil count and neutrophil/ lymphocyte ratio in predicting in-hospital mortality and complications after STEMI. J
Cardiovasc Thorac Res. 2014;6(1):35-41.

16. Georges Q Azoulay E, Mokart D, Soares $M$, Jeon $K$, Oeyen $S$, dkk. Influence of neutropenia on mortality of critically ill cancer patients: results of a metaanalysis on individual data. Crit Care. 2018;22(1):326.

17. Azab B, Chainani V, Shah N, McGinn JT. Neutrophil-lymphocyte ratio as a predictor of major adverse cardiac events among diabetic population: A 4-year follow-up study. Angiology. 2013;64(6):456-65.

18. Liu X, Shen Y, Wang H, Ge Q, Fei A, Pan S. Prognostic significance of neutrophil-tolymphocyte ratio in patients with sepsis: a prospective observational study. Mediators Inflamm. 2016;2016(1):1-8.

19. Yamanaka T, Matsumoto $S$, Teramukai S, Ishiwata R, Nagai Y, Fukushima M. The baseline ratio of neutrophils to lymphocytes is associated with patient prognosis in advanced gastric cancer. Oncology. 2008;73(3-4):215-20.

20. Tamhane UU, Aneja S, Montgomery D, Rogers EK, Eagle KA, Gurm HS. Association between admission neutrophil to lymphocyte ratio and outcomes in patients with acute coronary syndrome. Am J Cardiol. 2008;102(6):653-7. 